University of Michigan Law School

University of Michigan Law School Scholarship Repository

Law \& Economics Working Papers

$1-28-2018$

\title{
The Elephant Always Forgets: US Tax Reform and the WTO
}

\author{
Reuven S. Avi-Yonah \\ University of Michigan Law School, aviyonah@umich.edu \\ Martin G. Vallespinos \\ University of Michigan Law School, mvalles@umich.edu
}

Follow this and additional works at: https://repository.law.umich.edu/law_econ_current

Part of the Law and Economics Commons, and the Tax Law Commons

\section{Working Paper Citation}

Avi-Yonah, Reuven S. and Vallespinos, Martin G., "The Elephant Always Forgets: US Tax Reform and the WTO" (2018). Law \& Economics Working Papers. 151.

https://repository.law.umich.edu/law_econ_current/151

This Article is brought to you for free and open access by University of Michigan Law School Scholarship Repository. It has been accepted for inclusion in Law \& Economics Working Papers by an authorized administrator of University of Michigan Law School Scholarship Repository. For more information, please contact mlaw.repository@umich.edu. 
Avi-Yonah and Vallespinos:

\title{
DRAFT 1/28/18
}

\section{THE ELEPHANT ALWAYS FORGETS: US TAX REFORM AND THE WTO}

\author{
Reuven S. Avi-Yonah ${ }^{1}$ and Martin G. Vallespinos ${ }^{2}$
}

\begin{abstract}
The "Tax Cuts and Jobs Act" (TCJA) enacted on December 22, 2017 includes several provisions that raise WTO compliance issues. At least one such provision, the ForeignDerived Intangible Income (FDII) rule, is almost certain to draw a challenge in the WTO and is likely to lead to another US loss and resulting sanctions. This outcome would be another addition to the repeated losses suffered by the US for export subsidies from the 1970s to 2004, which led to the imposition of sanctions and the ultimate repeal of the offending regime. The important question for 2018 and beyond is whether the Trump administration and its Congressional allies will react to such a loss in a similar fashion as the Bush administration did in 2004, or whether it will defy the WTO, with potential farreaching consequences for the world trade order.
\end{abstract}

\section{Introduction: Tax and Trade}

Since the origins of the world trade regime, it has been clear that tax laws can undermine the proper functioning of trade rules in two main ways. First, taxes can serve as tariff barriers if they are imposed on imports but not on domestic sales. Second, remission of taxes on exports can serve as an export subsidy. ${ }^{3}$

The first type of tax measure violates GATT II:1(b) because it is an unscheduled charge on importation that is not an "ordinary customs duty." Alternatively, if the tax is imposed on importers but not on domestic sellers, it may violate GATT III:2 as a discriminatory internal tax.

\footnotetext{
${ }^{1}$ Irwin I. Cohn Professor of Law, the University of Michigan. We would like to thank Don Regan, Greg Shaffer.

${ }^{2}$ SJD candidate, the University of Michigan.

${ }^{3}$ See generally Avi-Yonah and Slemrod, (How) Should Trade Agreements Address Income Tax Issues,55 Tax L. Rev. 533 (2002); Avi-Yonah, The WTO, Export Subsidies, and Tax Competition, in Michael Lang, Judith Herdin and Ines Hofbauer (eds.), WTO and Direct Taxation 115 (Linde, 2005); Avi-Yonah, Treating Tax Issues Through Trade Regimes, 26 Brooklyn J. Int'1 L. 1683 (2001); Avi-Yonah, Tax, Trade, and Harmful Tax Competition: Reflections on the FSC Controversy, 21 Tax Notes Int'1 2841 (Dec. 18, 2000).
} 
The second type of tax measure violates the Subsidies and Countervailing Measures Agreement ("SCM Agreement"), which applies to goods but not to services. Article 1 of the SCM Agreement defines a subsidy as a financial contribution by a government conferring a benefit, which includes: the direct transfers of funds, goods, or services (other than infrastructure), and the non-collection or forgiveness of taxes otherwise due. The SCM Agreement distinguishes three categories of subsidies: prohibited subsidies, non-actionable subsidies, and actionable subsidies. The prohibited subsidies category, described in Article 3 of the SCM Agreement, includes:

a. Subsidies that are contingent, in law or in fact, upon export performance, and

b. Subsidies that are contingent upon the use of domestic over imported goods.

These subsidies are prohibited outright and countries are allowed to unilaterally impose countervailing measures against the country that created them.

Annex I of the SCM agreement provides an illustrative list of the prohibited export subsidies, but also provides two exceptions. One exception is for indirect tax exemptions, remissions or deferral of prior-stage cumulative taxes levied on inputs that are consumed in the production of the exported product. ${ }^{4}$ The second exception is for exemptions, remissions, or deferrals that are intended to avoid double taxation of foreign-source income. ${ }^{5}$

On the other side of the spectrum, the actionable subsidies category includes any other subsidies that are not considered "prohibited" and that satisfy the following two additional requirements:

a. Specificity: An actionable subsidy is considered specific when the eligibility to receive the benefits is limited to certain enterprises, industries, or areas (article 2 of the SCM Agreement), and;

b. Adverse effect: An actionable subsidy is considered adverse when it produces a serious prejudice to the interests of another member, an injury to its domestic industry, or a nullification or impairment of benefits accruing directly or indirectly to other members under the General Agreement on Tariffs and Trade (GATT) 1994 (article 5 of the SCM Agreement).

When an actionable subsidy is specific and produces an adverse effect, the affected countries are entitled to file a formal complaint with the WTO Dispute Settlement Body, and may impose retaliatory sanctions in the event that the complaint is upheld.

\footnotetext{
${ }^{4}$ Agreement on Subsidies and Countervailing Measures, Apr. 15, 1994, Marrakesh Agreement Establishing the World Trade Organization, Annex I, paragraphs H and I.

${ }^{5}$ Agreement on Subsidies and Countervailing Measures, Apr. 15, 1994, Marrakesh Agreement Establishing the World Trade Organization, Annex I, footnote 59.
} 
For the first five years after its entry into force, the SCM Agreement contained a third category of subsidies: The non-actionable subsidies. The non-actionable subsidy provisions, as defined in Articles 8 and 9 of the SCM Agreement, were certain narrowlydefined specific subsidies for research and development, for adaptation of existing facilities to new environmental regulations, and for assistance to disadvantaged regions. These subsidies were selected for non-actionable status on the basis that they furthered important policy goals and were unlikely to have harmful effects on trade. The provisions on non-actionable subsidies applied provisionally for a period of five years, and expired at the end of 1999.

The TCJA includes two measures that potentially violate these rules: The Base Erosion Anti-Abuse Tax, or BEAT (Internal Revenue Code (IRC) section 59A), which can be seen either as imposing a hidden tariff or as creating an export subsidy, and the Foreign Derived Intangible Income provision, or FDII (IRC section 250), which can be seen as an export subsidy.

\section{The BEAT}

Under new IRC section 59A, US corporate taxpayers must pay an additional "base erosion anti-abuse tax" (BEAT) to the extent that the "base erosion minimum tax amount" for the taxable year exceeds their regular tax liability (including the foreign tax credit and other tax credits, but excluding the R\&D tax credit). The "base erosion minimum tax amount" equals $10 \%{ }^{6}$ of the taxpayer's modified taxable income. To determine the modified taxable income, a taxpayer must compute its taxable income for the year without regard to any payment to a foreign related party with respect to which a deduction is allowed, including interest (to the extent not otherwise disallowed), management fees, ${ }^{7}$ royalties, and, for inverted corporations, also cost of goods sold. Such payments also include any amount paid or accrued by the taxpayer to a related party for the acquisition of depreciable property, reinsurance payments to a foreign related party, and the "base erosion percentage" of an NOL carried forward from a previous year. There is a safe harbor for smaller corporations with average annual gross receipts for the last three years below $\$ 500$ million, and another for corporations with a base erosion percentage below $3 \%$. The base erosion percentage is determined by dividing the aggregate amount of base erosion tax benefits of the taxpayer for the taxable year by the aggregate amount of the deductions allowable to the taxpayer. Finally, new Section 59A applies to base erosion payments paid or accrued in taxable years beginning after December 31, 2017.

The BEAT was enacted to address concerns about deductible payments to related parties being used to erode the US corporate tax base. This concern originally applied primarily in the context of inversions, because a major reason for inversions was that following the

\footnotetext{
${ }^{6}$ For the first taxable year beginning after December 31, 2017, the "base erosion minimum tax amount" equals $5 \%$ of the taxpayer's modified taxable income.

${ }^{7}$ A base erosion payment does not include any amount paid or accrued by a taxpayer for services if such services meet the requirements for eligibility for use of the services cost method described in Treas. Reg. sec. 1.482-9.
} 
inversion (i.e., making the US parent a subsidiary of new foreign parent) it was possible to load up the US parent with debt, generating deductible interest payments to new foreign parent in a low-tax jurisdiction. But the BEAT reaches more broadly, as it applies not only to payments to foreign parents but also to payments to foreign subsidiaries.

The BEAT was enacted in lieu of a much broader House provision that would have applied a $20 \%$ excise tax to all deductible payments to foreign related parties including cost of goods sold. Such a provision would have been a probable violation of the antitariff rule of GATT II:1(b), because it would be an unscheduled charge on importation of goods, and of the non-discrimination provision of GATT III:2, because it would only apply to payments to foreign parties.

The BEAT is much narrower, and most of it applies to interest and royalties, which are not covered by GATT and by the SCM Agreement. However, there are three aspects of BEAT that can potentially violate the GATT and SCM rules. Two of them are not likely to occur frequently in practice, and the remaining aspect has historically been subject to little WTO enforcement.

The first is the imposition of BEAT on the import of depreciable property. Since this does not include inventory or parts (which are not depreciable), it would seem unlikely that it would be imposed frequently enough to warrant a WTO challenge, because the scope of permitted countervailing measures would be quite limited.

The second and potentially more troubling aspect of BEAT is its imposition on cost of goods sold in the context of inversions. This can be quite broad and lead to a WTO violation. However, the provision only applies to post November 2017 inversions that qualify as such under the definitions of IRC section 7874, and no inversion after section 7874 was enacted in 2004 has qualified as such because the 7874 definition is relatively easy to avoid (and was left unchanged by TCJA). Thus, it seems unlikely that the BEAT would actually ever apply to cost of goods sold in practice.

The third aspect is the preferential treatment of $\mathrm{R} \& \mathrm{D}$ credits in the computation of BEAT. Section 59A(b)(1)(B)(ii) provides that, for purposes of calculating BEAT, the R\&D tax credit claimed by the taxpayer for the taxable year should be added back to the regular tax liability. This means that the dollar-for-dollar tax benefit provided by the $\mathrm{R} \& \mathrm{D}$ tax credit is preserved without regard to a taxpayer's BEAT position. This subtle amendment has put the R\&D credit in a better position compared with most of the remaining tax credits (e.g. FTC). When the SCM entered into force, the R\&D subsidies were included in the non-actionable subsidies category (Art. 8), meaning that they were presumed not to distort trade. These provisions were controversial and the non-actionable category was finally allowed to lapse in 1999. Since then, R\&D subsidies have been in the area of "actionable subsidies", meaning that they can be challenged, either by dispute settlement or unilateral countervailing duties. However, to challenge these subsidies, the complainant country must demonstrate that the subsidy is specific and has injurious effects on another WTO Member. Despite this change to a more vulnerable legal status, 
R\&D subsidies have been the subject of relatively little WTO enforcement. ${ }^{8}$ As a standalone measure, it is not expected that the privileged position of the R\&D credit would trigger a WTO challenge. However, from a policy perspective, these incentives are coordinated with the FDII deduction and the GILTI inclusion (analyzed below), so they could potentially be linked with export activity, then falling in the category of prohibited subsidies. Alternatively, following the lessons from the Boeing case, they could be considered part of a bigger group of tax incentives that in the overall result in a serious prejudice to the interests of another Member, thus falling in the category of a disallowed actionable subsidy.

\section{The FDII}

TCJA and new IRC sections $951 \mathrm{~A}$ and 250 provide that a $10.5 \%$ tax will apply to the Global Intangible Low Tax Income ("GILTI") earned by a foreign subsidiary of a US multinational ("CFC"). GILTI income is the "net tested income" of a foreign subsidiary that exceeds a $10 \%$ rate of return on its tangible assets. Since only a portion ( 80 percent) of foreign tax credits are allowed to offset the US taxes applicable to GILTI income, the minimum foreign tax rate at which no U.S. residual tax is owed by a domestic corporation is $13.125 \%$. Because this rate is lower than the new US corporate rate of $21 \%$ and because there is no longer a tax imposed on dividends from CFCs to their US parents, a concern arose that there will be increased incentive to shift income from the US parents to CFCs in lower tax jurisdictions.

To address the problem of shifting income from the US to CFCs, new IRC section 250 applies a reduced $13.125 \%$ rate to "foreign derived intangible income" (FDII) which is the portion of a US taxpayer "deemed intangible income" (determined on a formulaic basis) that is derived from serving foreign markets.

Deemed intangible income is the excess of a domestic corporation's "deduction eligible income" (gross income without regard to certain enumerated categories) over its "deemed tangible income return" (10\% of its tangible assets).

For the computation of its FDII, a US taxpayer must multiply its deemed intangible income by the percentage of its deduction eligible income that is foreign-derived. The "foreign derived deduction eligible income" is defined as income derived in connection with (1) property that is sold by the taxpayer to any foreign person for a foreign use or (2) services to any foreign person or with respect to foreign property. In other words, this category comprises exports for property and services, including royalties from the licensing of intangibles. The deduction eligible income is essentially the domestic corporation's modified gross income. So, a U.S. company's foreign derived intangible income, which gets the $13.125 \%$ rate, is the amount that bears the same ratio to the deemed intangible income as the U.S. company's exports bear to its modified gross income.

${ }^{8}$ Maskus, Keith. Research and Development Subsidies: A Need for WTO Disciplines?

E15Initiative. Geneva: International Centre for Trade and Sustainable Development (ICTSD) and World Economic Forum, 2015, www.e15initiative.org/. 
While services are excluded from the SCM, the FDII provision clearly applies a lower rate (13.125\% instead of $21 \%$ ) to a domestic US corporation's sales of goods to any foreign person for a foreign use. It is likely that importing goods and then re-exporting them without significant modification will qualify for the lower rate. ${ }^{9}$ Moreover, it is clear that exporting goods, modifying them, and then importing them to the US qualifies for the lower rate. ${ }^{10}$

FDII clearly involves the non-collection or forgiveness of taxes otherwise due, i.e., a subsidy under the SCM, and the subsidy is likewise clearly contingent in law and in fact upon export performance. Thus, there is little doubt that the FDII provision is prohibited subsidy in violation of the SCM. Such a subsidy entitles trading partners to impose sanctions, either unilaterally or after receiving approval from the WTO's Dispute Resolution Body.

\section{How Will the US Respond to Another WTO Loss?}

The FDII is just the latest in a long series of US export subsidies that were struck down by the WTO and its predecessor the GATT. The first adverse decision was a GATT panel that declared the US "Domestic International Sales Corporation" (DISC) regime to be a prohibited export subsidy in the 1970s. A DISC was a domestic subsidiary of a US corporation operating as an export agent of the parent. The main benefit of having a DISC was that $50 \%$ of the DICS's export income was sheltered from federal income taxes until distribution. In addition, DISC companies were subject to more favorable intercompany pricing rules, which deviated from the arm's length principle, and resulted in DISC's export prices being lower than their domestic counterparts.

\footnotetext{
${ }^{9}$ See Michael Schler, Reflections on the Pending Tax Cuts and Jobs Act (Tax Forum no. 686, Dec. 4, 2017). See also Avi-Yonah, Reuven S. and Batchelder, Lily L. and Fleming, J. Clifton and Gamage, David and Glogower, Ari D. and Hemel, Daniel Jacob and Kamin, David and Kane, Mitchell and Kysar, Rebecca M. and Miller, David S. and Shanske, Darien and Shaviro, Daniel and Viswanathan, Manoj, The Games They Will Play: Tax Games, Roadblocks, and Glitches Under the New Legislation (December 7, 2017). Available at SSRN: https://ssrn.com/abstract=3084187 or http://dx.doi.org/10.2139/ssrn.3084187 and Avi-Yonah, Reuven S. and Batchelder, Lily L. and Fleming, J. Clifton and Gamage, David and Glogower, Ari D. and Hemel, Daniel Jacob and Kamin, David and Kane, Mitchell and Kysar, Rebecca M. and Miller, David S. and Shanske, Darien and Shaviro, Daniel and Viswanathan, Manoj, The Games They Will Play: An Update on the Conference Committee Tax Bill (December 18, 2017). Available at SSRN: https://ssrn.com/abstract=3089423.

${ }^{10}$ See Conference Report, fn. 1522: "If property is sold by a taxpayer to a person who is not a U.S. person, and after such sale the property is subject to manufacture, assembly, or other processing (including the incorporation of such property, as a component, into a second product by means of production, manufacture, or assembly) outside the United States by such person, then the property is for a foreign use." http://docs.house.gov/billsthisweek/20171218/Joint\%20Explanatory\%20Statement.pdf.
} 
The DISC regime was replaced by the "Foreign Sales Corporation" (FSC) regime ${ }^{11}$. The FSC regime essentially exempts a portion of an FSC's export-related foreign-source income from United States income tax. ${ }^{12}$ But the main difference with the DISCs is that the FSC needs to be incorporated in a qualified offshore location (e.g. Barbados and the US Virgin Islands), and meet certain other requirements relating to its foreign presence, to the keeping of records, and to its shareholders and directors. Under these rules, a portion of the FSC's export-related foreign source income is legislatively determined not to be "effectively connected income" and, therefore, is not taxable in the hands of the FSC. In addition, the US shareholder of the FSC is generally exempted from Subpart F on its export related foreign source income, and also enjoys a 100\% deduction on distributions from the FSC to the extent they are related to this income. In the late 1990s, the WTO Panel found the FSC constituted a prohibited subsidy pursuant to article 3.1(a) of the SCM Agreement. The FSC was deemed export contingent as it was only available to (i) foreign trading income, (ii) the foreign trading income arising on the sale or lease of "export property", and (iii) the export property was limited to goods arising, manufactured, produced or extracted in the United States.

As a result of this set back, the US Congress repealed the FSC rules and introduced, in the same Act ${ }^{13}$, the "Extraterritorial Income" (ETI) regime. The ETI Act was promulgated by the United States with a view to complying with the recommendations and rulings of the WTO in the US - FSC dispute. Under the ETI regime (IRC section 114) a taxpayer can exclude a portion of its "extraterritorial income" from its "gross income" for purposes of calculating his or her Federal income tax liability. Extraterritorial income generally includes earnings from sales, rental, or services that involve "qualifying foreign trade property", which is property: (A) manufactured, produced, grown or extracted within or outside the United States; (B) held primarily for sale, lease or rental, in the ordinary course of business, for direct use, consumption, or disposition outside the United States; and (C) not more than 50 percent of its fair market value can be attributable to foreign content (including foreign supply and foreign direct costs of labor). In addition, to qualify as extraterritorial income, the income arising from the transaction must satisfy the "foreign economic process requirement" This requirement will be satisfied, generally speaking, where at least some of the activities comprising the transaction take place outside the United States. The portion of the extraterritorial income that is excluded from gross income under the ETI regulations was the greatest of, or the taxpayer's choice of, the following three options: (i) 30 percent of the foreign sale and leasing income derived by the taxpayer from such transaction; (ii) 1.2 percent of the foreign trading gross receipts derived by the taxpayer from the transaction; or (iii) 15 percent of the foreign trade income derived by the taxpayer from the transaction. Finally, where a taxpayer elects to use the ETI measure, it must give up any tax credits it has obtained through taxation of its income in a foreign jurisdiction that are attributable to the QFTI excluded from taxation.

The ETI regime was declared to be a prohibited export subsidy in 2004. This led the GOP-controlled Congress and the Bush administration to repeal the ETI and replace it

${ }^{11}$ Tax Reform Act of 1984.

${ }^{12} \mathrm{WT} / \mathrm{DS} 108 / \mathrm{AB} / \mathrm{R}$.

${ }^{13}$ United States Public Law 106-519, 114 Stat. 2423 (2000). 
with a domestic manufacturing provision (IRC section 199) that did not violate the SCM because it was not contingent on export performance.

This history was well known to the drafters of TCJA. In fact, the FDII provision is a direct descendant of the "border adjusted tax" (BTA) that was proposed by the House Republicans in 2016 and that was broadly declared to be a violation of the SCM. ${ }^{14}$ Nevertheless, the drafters of TCJA decided to repeal IRC section 199 (which did not violate the SCM) and replace it with the FDII, which (unlike, for example, the ETI) is a blatant and obvious violation of the SCM. ${ }^{15}$

The FDII has a very low chance of surviving a WTO challenge, even lower than the previous US export subsidies that were ultimately struck down by the WTO. Not only because the FDII clearly satisfies the definition of a "prohibited subsidy" under the SCM Agreement, but also because this new attempt is inconsistent with the main arguments raised by the US during its longstanding trade dispute with the WTO ("the FSC-US litigation").

Putting aside the procedural issues (e.g. panel expertise, appropriate tax forum, availability of evidence, etc.) and certain definitional divergences, the central arguments advanced by the US during the US-FSC litigation were the "the rebalancing argument" and the "double tax argument".

The rebalancing argument: The US argued that the export-oriented tax breaks enacted by the US, instead of subsidizing exports, were intended to correct the imbalance suffered by the US exporters, who are subject to worldwide taxation and do not benefit from a federal indirect tax system that rebates taxes at the border.

Under the US vision, US export multinationals are at a disadvantage compared with their European counterparts. This is because many European multinationals enjoy the benefits of the territorial system of taxation, meaning that they are generally not taxed on profits earned by their foreign sales subsidiaries (or branches), and/or on subsequent distributions of such profits. Therefore, the US alleged that the main role of the export related tax breaks was to establish an economic equivalence with the benefits provided by the territorial tax system of taxation. Following the US - DISC dispute, the US argued that the provisions at issue "were intended to provide a limited territorial-type system of taxation to redress this unbalance" 16 . This key US argument will clearly be outdated in a potential WTO litigation regarding the FDII. The FDII tax break is part of a larger tax reform package which includes the shift of the US tax system toward territoriality. In the new US tax system, US corporate shareholders may deduct $100 \%$ of the foreign-source portion of dividends from 10\% owned foreign corporations (excluding certain "hybrid"

\footnotetext{
${ }^{14}$ See Avi-Yonah and Clausing, Problems with Destination-Based Corporate Taxes and the Ryan Blueprint, 8 Columbia J. Tax L. 229 (2017).

${ }^{15}$ This issue was raised by Rebecca Kysar well before TCJA was enacted. See Rebecca Kysar, The Senate Tax Plan Has WTO Problems, Medium.com (Nov. 12, 2017), https://medium.com/whatever-source-derived/the-senate-tax-plan-has-a-wto-problem-guest-postby-rebecca-kysar-31deee86eb99.

${ }^{16}$ Jennifer E. Farrell, The Interface of International Trade Law and Taxation 140 (2011).
} 
dividends). In addition, the earnings and profits of a US owned foreign corporation are not subject to tax, except for certain categories of income (e.g. Subpart F income, GILTI income). This means that US multinationals are now enjoying same type of territoriality benefits as their European counterparts, so it seems that there is no longer an unbalance that needs to be redressed.

Further, the FDII cannot be used to correct the unbalance generated by the "discriminatory" BTAs, because the FDII technically is a deduction allowed in the context of the income tax. Annex II of the SCM agreement provides that taxes levied on inputs consumed in the production of an exported product can be rebated (with certain limits). But this rebate, intended to avoid double taxation, only applies in the field of indirect taxation. The FDII is a part of the US income tax, and its liaison with direct taxation is even more clear than in the case of some predecessors (e.g. BTA, excise tax, etc). Therefore, unless the US obtains a revision of the WTO rules with respect to the treatment of border adjustments for internal taxes, the chances of this argument to succeed are pretty low. In addition, BTAs are intended to prevent double taxation in the field of indirect taxation, so it is unlikely that the WTO would extend these rules to the income tax which has its own mechanisms to prevent double taxation.

The double tax argument: As an alternative argument, the US alleged that even if the tax break given to exporters involved export contingent subsidies, these subsidies would not be prohibited because the fifth sentence of footnote 59 to the SCM Agreement permits a Member to take measures granting special fiscal treatment to "foreign-source income" in order to alleviate a "double taxation" burden on its taxpayer. The fifth sentence of footnote 59, therefore, constitutes an exception to the legal regime applicable to export subsidies under Article 3.1(a) of the SCM Agreement by explicitly providing that when a measure is taken to avoid the double taxation of foreign-source income, a Member is entitled to adopt it. The WTO Appellate Body has interpreted that the fifth sentence of footnote 59 allows Members to "take", or "adopt" measures to avoid double taxation of foreign-source income, notwithstanding that they may be, in principle, export subsidies within the meaning of Article 3.1(a) of the SCM agreement. ${ }^{17}$ The term "foreign-source income" in footnote 59 refers to income which is susceptible of being taxed in two States. This means income generated by activities of a non-resident taxpayer in a "foreign" State which have such links with that State so that the income could properly be subject to tax in that State. ${ }^{18}$ The determination of whether the activities of the non-resident taxpayer are linked with the foreign country is based on the general principles of the international tax system, which are imbedded in the tax treaty network, domestic law, and generally accepted practices.

The FDII regime provides a reduced $13.125 \%$ rate to the foreign portion of a US taxpayer's deemed intangible income. Such foreign portion includes: (i) Income from the sale of property by the taxpayer to a non US person for a foreign use (export of goods); (ii) Income from services provided with respect to property or a person not located in the US (export of services).

${ }^{17} \mathrm{WT} / \mathrm{DS} 108 / \mathrm{AB} / \mathrm{R}$.

${ }^{18} \mathrm{Id}$. 
Under the general principles of the international tax system, income from exports to a foreign country are typically not subject to income taxes in such foreign country. The longstanding rule of exclusive residency based taxation on export sales income is included in the Permanent Establishment ("PE") provision of every double tax treaty. The treaties generally provide that a non-resident exporter with no fixed place of business, office, or agent in the destination country would not trigger a PE, and therefore, would not be subject to income taxes in that foreign country. Further, most countries have a similar provision in their domestic tax law. The US domestic tax regime, for example, provides that the direct export of products to US customers by a non-resident is not viewed as a US trade or business and does not trigger income taxes in the US for the nonresident exporter (assuming that the foreign corporation does not have a US office or agent, marketing, or direct solicitation activities in the US). ${ }^{19}$ This general understanding has been reinforced by the TCJA, which modified the sourcing rules for sales income provided by Section 863(b). Under new Section 863(b), gains, profits, and income from the sale or exchange of inventory property produced in the United States are exclusively sourced to the country where the products are manufactured.

In light of these provisions, the argument that the FDII would prevent double taxation is expected to be even more fragile than in the case of its immediate predecessors. In this regard, the ETI regime included a "foreign economic process requirement", which to some extent supported the view that this regime was intended to prevent double taxation. But the FDII does not include a foreign requirements, and is granted to any US exporter notwithstanding its foreign involvement or the structure of its supply chain. Therefore, we can anticipate that the FDII may not be successfully protected with the "double taxation argument" in the case of being subject to a WTO dispute.

Given its weakness, it is almost certain that the FDII will draw a challenge in the WTO. Before the TCJA was finalized and signed into law by President Trump, the finance ministers of Europe's five largest economies, communicated to the White House and the US Department of the Treasury their view regarding the potential violations of WTO obligations perpetrated by the FDII. This communication was an obvious warning of European retaliation.

The fragility of the FDII regimes raises the question of whether the current administration and the Republican majorities in Congress would react to another WTO loss and sanctions in the same way as the Bush Administration and its GOP Congressional majorities reacted in 2004, i.e., by repealing the offensive provision. I believe the answer is probably no. Here is the reply to this question provided by a senior GOP lobbyist:

"Top USTR staff told me in March 2017 that the WTO will likely, one day, take on the Trump administration. The implication was that the future of the WTO would be at risk because the economic nationalists are WTO skeptics... Sovereignty is a big issue for the administration. It is also big among lefty fair traders. The WTO should not be able to overrule US laws.

${ }^{19}$ Linen Thread Co. v. Comr., 14 T.C. 725 (1950). 
Tax is something the GOP free traders care deeply about. If a country took us on at the WTO, the GOP opposition to the WTO would grow. If the WTO rules against us, the remedy is to authorize tariffs by the petitioner against US goods or services of the petitioner's choice. The WTO does not directly change domestic US law after a ruling. The US could simply pay those tariffs as it has in one or two cases in the past.

Or the US could increase its challenge to the WTO in ways that USTR Bob Lighthizer would likely be creative about. In addition to what he is doing now... (1) preventing the re-authorization of the term of a WTO judge on grounds that he rules on the basis of doctrine not contained in the WTO agreement, or (2) preventing the WTO negotiation functions from achieving new agreements.

The National Security Strategy released by the administration last Monday basically said that liberalizing trade with China was a mistake because the assumption that China would be more democratic and capitalistic ended up wrong. Lighthizer has said that the WTO is ill-equipped to handle comprehensive state-capitalism, and ill-equipped to handle the varying economic systems and development levels of all its members.

This is a long way of saying - I'm not sure. But any WTO challenge could threaten the existence or efficacy of the WTO because of this context. Or threaten the US willingness to continue as a member. As between tax cuts and the WTO, the GOP free traders would likely choose tax cuts."

\section{Conclusion}

If the GOP lobbyist is to be believed, a WTO challenge to the FDII could result in a major clash between the US and the WTO, with potentially disastrous consequences. Even if he is exaggerating, the willingness of the GOP Congressional majorities to defy the WTO stands in stark opposition to the way the GOP behaved in 2004. This relatively obscure tax issue could have very troubling long-term implications. 